\title{
Bio-based rhamnolipids production and recovery from waste streams: Status and perspectives
}

\author{
Sunita Varjani ${ }^{\mathrm{a}, *}$, Parita Rakholiya ${ }^{\mathrm{a}, \mathrm{b}}$, How Yong $\mathrm{Ng}^{\mathrm{c}}$, Mohammad J. Taherzadeh ${ }^{\mathrm{d}}$, \\ Huu Hao Ngo ${ }^{e}$, Jo-Shu Chang ${ }^{f}$, Jonathan W.C. Wong ${ }^{g}$, Siming You ${ }^{\text {h }}$, Jose A. Teixeira ${ }^{i}$, \\ Xuan-Thanh Bui ${ }^{\mathrm{j}, \mathrm{k}}$ \\ ${ }^{\text {a }}$ Gujarat Pollution Control Board, Gandhinagar, Gujarat 382 010, India \\ ${ }^{\mathrm{b}}$ Kadi Sarva Vishwavidyalaya, Gandhinagar, Gujarat 382015, India \\ ${ }^{\mathrm{c}}$ National University of Singapore Environmental Research Institute, 5A Engineering Drive 1, Singapore 117411, Singapore \\ ${ }^{\mathrm{d}}$ Swedish Centre for Resource Recovery, University of Borås, 50190 Borås, Sweden \\ e Centre for Technology in Water and Wastewater, School of Civil and Environmental Engineering, University of Technology Sydney, Sydney, NSW 2007, Australia \\ ${ }^{\mathrm{f}}$ Department of Chemical and Materials Engineering, Tunghai University, Taichung, Taiwan \\ ${ }^{\mathrm{g}}$ Institute of Bioresource and Agriculture, Hong Kong Baptist University, Hong Kong \\ ${ }^{\mathrm{h}}$ James Watt School of Engineering, University of Glasgow, Glasgow G12 8QQ, UK \\ ${ }^{i}$ CEB - Centre of Biological Engineering, University of Minho, 4710057 Braga, Portugal \\ ${ }^{\mathrm{j}}$ Faculty of Environment and Natural Resources, Ho Chi Minh City University of Technology (HCMUT), Ho Chi Minh City 700000, Viet Nam \\ ${ }^{\mathrm{k}}$ Key Laboratory of Advanced Waste Treatment Technology, Vietnam National University Ho Chi Minh (VNU-HCM), Linh Trung ward, Thu Duc district, Ho Chi Minh \\ City 700000, Viet Nam
}

\section{H I G H L I G H T S}

- Rhamnolipid can be recovered from waste streams.

- The major stumbling block in rhamnolipid production is cost of production.

- Various applications of Rhamnolipid have been explained.

- Summarised opportunities for research innovations in bio-based rhamnolipids field.

\section{A R T I C L E I N F O}

\section{Keywords:}

Rhamnolipid

Scale-up process

Remediation

Enhanced oil recovery

Oily waste

Agro-industrial waste
G R A P H I C A L A B S T R A C T

\footnotetext{
* Corresponding author.

E-mail address: drsvs18@gmail.com (S. Varjani).
} 


\section{Introduction}

Surfactants are amphiphilic molecules that help to reduce interfacial tension between two different phases (solid-liquid, air-liquid and liquid-liquid) and allow them to mix and interact more easily (JiménezPeñalver et al., 2019; Conceição et al., 2020). Based on surface properties and chemical structure, surfactants can act as wetting agents, dispersants, detergents, foaming agents and emulsifiers (Varjani and Upasani, 2017b; Moshtagh et al., 2018). Surfactants are used in almost every product of daily life from which half of the total production is used in food, textiles, cosmetics, mining, pharmaceuticals, agriculture, etc. and other half is used in laundry and household detergents (Renterghem et al., 2018; Jiménez-Peñalver et al., 2019).

Biosurfactants are surface-active agents produced by a wide range of microorganisms (fungi, bacteria, yeast) as secondary metabolites (Díaz De Rienzo et al., 2016; Kourmentza et al., 2017). Biosurfactant producing microorganism and the yield has been narrated in Table 1. Biosurfactants can be classified based on their molecular weight, chemical structure and organisms that produce them. Fatty acids, neutral lipids and phospholipids; glycolipid, particulate and polymeric biosurfactants; lipoproteins and lipopeptides are classified based on their chemical structure (Moshtagh et al., 2018). Based on molecular weight, biosurfactants classified into two major groups (a) high molecular weight biosurfactants and (b) low molecular weight biosurfactants. Surface properties of biosurfactants vary due to the presence of different chemical structures (Jiménez-Peñalver et al., 2019). Biosurfactants are alternative to synthetic surfactants due to (i) cost effective production from waste materials or renewable feedstock; (ii) contain great environmental compatibility, low toxicity and biodegradable; and (iii) shown stable activity at extreme temperature, $\mathrm{pH}$ and salinity (Henkel et al., 2017; Varjani and Upasani, 2017b; Jiang et al., 2019; Wang et al., 2020).

Table 1

Biosurfactant producing microbes.

\begin{tabular}{|c|c|c|c|c|}
\hline $\begin{array}{l}\text { Sr. } \\
\text { No. }\end{array}$ & Biosurfactants & Microbial culture & Yield & References \\
\hline \multirow[t]{6}{*}{1} & Sophorolipid & Starmerella ombicola & $\begin{array}{l}115.2 \\
\mathrm{~g} / \mathrm{L}\end{array}$ & $\begin{array}{l}\text { Kaur et al., } \\
2019\end{array}$ \\
\hline & & $\begin{array}{l}\text { Candida albicans SC5314 } \\
\text { and Candida glabrata } \\
\text { CBS138 }\end{array}$ & - & $\begin{array}{l}\text { Gaur et al., } \\
2019 b\end{array}$ \\
\hline & & Candida bombicola & $623 \mathrm{~g} / \mathrm{L}$ & $\begin{array}{l}\text { Dolman et al., } \\
2017\end{array}$ \\
\hline & & Starmerella bombicola & $\begin{array}{l}26 \mathrm{~g} / \mathrm{L} \\
21 \mathrm{~g} / \mathrm{L} \\
19 \mathrm{~g} / \mathrm{L}\end{array}$ & $\begin{array}{l}\text { Shah et al., } \\
2017\end{array}$ \\
\hline & & $\begin{array}{l}\text { Cutaneotrichosporon } \\
\text { mucoides UFMG-CM- } \\
\text { Y6148 }\end{array}$ & $\begin{array}{l}0.167 \mathrm{~g} \\
\mathrm{~L}^{-1} \cdot \mathrm{h}^{-1}\end{array}$ & $\begin{array}{l}\text { Marcelino } \\
\text { et al., } 2019\end{array}$ \\
\hline & & Starmerella bombicola & - & $\begin{array}{l}\text { Huang and } \\
\text { Wages, } 2016\end{array}$ \\
\hline \multirow[t]{3}{*}{2} & Rhamnolipid & $\begin{array}{l}\text { Pseudomonas aeruginosa } \\
\text { DAB }\end{array}$ & $\begin{array}{l}17.3 \mathrm{~g} / \\
\mathrm{L}\end{array}$ & He et al., 2017 \\
\hline & & $\begin{array}{l}\text { Pseudomonas aeruginosa } \\
\text { KVD-HR42 }\end{array}$ & $\begin{array}{l}5.90 \pm \\
2.1 \mathrm{~g} / \mathrm{L}\end{array}$ & $\begin{array}{l}\text { Deepika et al., } \\
2016\end{array}$ \\
\hline & & $\begin{array}{l}\text { Pseudomonas aeruginosa } \\
\text { PAO1 }\end{array}$ & $\begin{array}{l}0.43 \mathrm{~g} / \\
\mathrm{L}\end{array}$ & $\begin{array}{l}\text { Radzuan et al., } \\
2017\end{array}$ \\
\hline \multirow[t]{4}{*}{3} & $\begin{array}{l}\text { Trehalose } \\
\text { lipids }\end{array}$ & Rhodococcus qingshengii FF & $\begin{array}{l}7.97 \mathrm{~g} / \\
\mathrm{L}\end{array}$ & $\begin{array}{l}\text { Wang et al., } \\
2019\end{array}$ \\
\hline & & Gordonia sp. 1D & - & $\begin{array}{l}\text { Delegan et al., } \\
2020\end{array}$ \\
\hline & & $\begin{array}{l}\text { Pseudomonas fragi ATCC } \\
4973\end{array}$ & $\begin{array}{l}2.89 \mathrm{~g} / \\
\mathrm{L}\end{array}$ & Mei et al., 2016 \\
\hline & & Rhodococcus erythropolis & $25 \mathrm{~g} / \mathrm{L}$ & $\begin{array}{l}\text { Patil and } \\
\text { Pratap, } 2018\end{array}$ \\
\hline \multirow[t]{2}{*}{4} & $\begin{array}{l}\text { Ornithine } \\
\text { lipid }\end{array}$ & Pseudomonas aeruginosa & - & $\begin{array}{l}\text { Lewenza et al., } \\
2011 \text {; Kim } \\
\text { et al., } 2018\end{array}$ \\
\hline & & Thiobacillus thiooxidans & - & Roy, 2017 \\
\hline
\end{tabular}

According to Jiménez-Peñalver et al. (2019) the global turnover of surfactants in 2016 was US $\$ 31$ Billion and by 2024 it is expected to grow US $\$ 40$ Billion. Surfactants have been used in soil remediation, degradation of crude oil, wastewater treatment, etc. (He et al., 2020). 344 thousand tons of biosurfactants were globally sold in 2013 and by 2020 it is expected to reach 461 thousand tons. Additionally, in 2016 the global market of biosurfactants was estimated at US\$3.99 billion and is expected to reach US $\$ 5.52$ billion by 2022 (Singh et al., 2018; Wang et al., 2018, 2020).

Most common biosurfactants are glycolipids and are formed of saccharides (mono, di, tri or tetra) of glucose, rhamnose, mannose or galactose that are attached to aliphatic acids (long-chain) with an ether or ester linkage. Most studied class of biosurfactants are rhamnolipids, which are anionic glycolipids formed of units of $\beta$ - hydroxyalkanoic acids and rhamnose residue (Pérez-Armendáriz et al., 2019). Literatures are available that show production of rhamnolipid using various waste materials such as refinery, petroleum, fruit, dairy, agricultural, bakery and other industrial waste. Waste materials used for the production of rhamnolipids are cost-effective. Rhamnolipids are highly used in various applications that include industrial (detergent, food, pharmaceutical, dairy, etc.), medical, bioremediation, microbial enhanced oil recovery.

The present review intends to expand the literature about production of rhamnolipids from different waste streams. It includes information about nature and chemical structure of rhamnolipids and scale-up of rhamnolipid production. It summarizes perspectives and challenges for research in rhamnolipid production from wastes. Already published literature at various periods have focused on a limited aspect in biobased rhamnolipid production. However this review provides comprehensive findings pertaining to developments in the topics presented as sections of this paper.

\section{Nature and chemical structure of rhamnolipid}

Rhamnolipids are a type of glycolipids, low molecular weight and most popular biosurfactant due to their great physicochemical properties (Zhao et al., 2018; Jahan et al., 2019; Varjani and Upasani, 2019; Drakontis and Amin, 2020). It is a diverse group of molecules with more than 60 reported congeners (Tiso et al., 2017). Rhamnolipid name is due to presence of rhamnose moiety, it is generally produced by Pseudomonas aeruginosa (Satpute et al., 2017). They contain fatty acid tail ( $\beta-$ hydroxydecanoic acid) with lengths of $8,10,12$ and 14 carbons and one or two glycosyl head groups (rhamnose moiety) (Elshikh et al., 2017; Henkel et al., 2017; Zhao et al., 2018; Pérez-Armendáriz et al., 2019). Rhamnolipids can be classified structurally based on presence of number of rhamnose group (i) monorhamnolipd and (ii) dirhamnolipid (Elshikh et al., 2017). Growth and environmental conditions influence production of rhamnolipids which can lead rhamnolipids with different degree of unsaturation, degree of branching and length of chain for fatty acids (Drakontis and Amin, 2020). According to Drakontis and Amin (2020) with the use of different concentration of bacterial species, 60 different rhamnolipid homologues and congeners can be produced. Rhamnolipids are more suitable for various industrial applications due to its great surface and biological activities (Zhao et al., 2018; Drakontis and Amin, 2020).

\section{Rhamnolipids from various waste streams}

Large amount of waste is produced each year by restaurants, houses and industries (Mishra et al., 2020). Improper disposal of waste can cause various environmental issues (Pérez-Armendáriz et al., 2019). Waste like oil, petroleum, agricultural and food can be used to produce various biosurfactants (rhamnolipids and sophorolipids, etc.) with help of various microbial cultures (Rajmohan et al., 2020). From all microorganisms, Pseudomonas aeruginosa is highly used for producing rhamnolipid because they can survive extreme environmental conditions ( $\mathrm{Li}$, 2017; Varjani et al., 2020a). 


\subsection{Oily waste}

Biosurfactants can be produced using industrial wastes such as food, oil refineries and petroleum oily waste as low cost raw material (Müller and Hausmann, 2011). Rhamnolipid production from different oily wastes employing microorganisms is shown in Table 2. PérezArmendáriz et al. (2019) have prepared 4 different factorial designs and performed 32 treatments for rhamnolipid production from which the highest rhamnolipid yield was obtained from factorial design 4 and treatment 8. Factorial design 4 contained waste canola oil as a source of carbon and sodium nitrate as a source of nitrogen and produced $3585.31 \pm 66.24 \mathrm{mg} / \mathrm{L}$ rhamnolipid using Pseudomonas aeruginosa. Ö zdal et al. (2017) have reported $12.1 \mathrm{~g} / \mathrm{L}$ production of rhamnolipid

Table 2

Rhamnolipid production from different oily wastes employing microorganisms.

\begin{tabular}{|c|c|c|c|c|}
\hline $\begin{array}{l}\text { Sr. } \\
\text { No. }\end{array}$ & Organisms & Type of waste & Yield & Reference \\
\hline 1 & $\begin{array}{l}\text { Pseudomonas aeruginosa } \\
\text { PAO1 }\end{array}$ & $\begin{array}{l}\text { Palm Fatty Acid } \\
\text { Distillate } \\
\text { (PFAD) }\end{array}$ & $\begin{array}{l}0.43 \mathrm{~g} / \\
\mathrm{L}\end{array}$ & $\begin{array}{l}\text { Radzuan et al., } \\
2017\end{array}$ \\
\hline 2 & $\begin{array}{l}\text { Pseudomonas aeruginosa } \\
\text { PrhlAB } \\
\text { Pseudomonas aeruginosa } \\
\text { SG } \\
\text { Pseudomonas stutzeri } \\
\text { Rhl }\end{array}$ & Crude glycerol & $\begin{array}{l}2.87 \mathrm{~g} / \\
\mathrm{L} \\
1.98 \mathrm{~g} / \\
\mathrm{L} \\
0.87 \mathrm{~g} / \\
\mathrm{L}\end{array}$ & Zhao et al., 2019 \\
\hline 3 & $\begin{array}{l}\text { Pseudomonas aeruginosa } \\
\text { MR01 }\end{array}$ & $\begin{array}{l}\text { SOM medium } \\
\text { including } \\
\text { soybean oil } 6 \% \\
\text { (V/V) }\end{array}$ & $\begin{array}{l}24-36 \\
\mathrm{mg} / \mathrm{L}\end{array}$ & $\begin{array}{l}\text { Lotfabad et al., } \\
2017\end{array}$ \\
\hline 4 & Pseudomonas aeruginosa & $\begin{array}{l}\text { Sunflower acid } \\
\text { oil }\end{array}$ & $4.9 \mathrm{~g} / \mathrm{L}$ & $\begin{array}{l}\text { Jadhav et al., } \\
2019\end{array}$ \\
\hline 5 & Pseudomonas aeruginosa & $\begin{array}{l}\text { Petroleum oil } \\
\text { wastes }\end{array}$ & $2.7 \mathrm{~g} / \mathrm{L}$ & $\begin{array}{l}\text { Mostafa et al., } \\
2019\end{array}$ \\
\hline 6 & $\begin{array}{l}\text { Stenotrophomonas } \\
\text { maltophilia IITR87 } \\
\text { Ochrobactrum anthropic } \\
\text { IITR07 } \\
\text { Pseudomonas aeruginosa } \\
\text { IITR48 }\end{array}$ & Crude oil & $\begin{array}{l}570 \\
\mathrm{mg} / \mathrm{L} \\
294 \\
\mathrm{mg} / \mathrm{L} \\
270 \\
\mathrm{mg} / \mathrm{L}\end{array}$ & $\begin{array}{l}\text { Tripathi et al., } \\
2019\end{array}$ \\
\hline 7 & $\begin{array}{l}\text { Pseudomonas aeruginosa } \\
\text { ORA9 }\end{array}$ & $\begin{array}{l}\text { Mineral } \\
\text { medium with } \\
\text { soybean fried } \\
\text { oil }\end{array}$ & $\begin{array}{l}2.3 \pm \\
0.8 \mathrm{~g} / \mathrm{L}\end{array}$ & $\begin{array}{l}\text { Gámez et al., } \\
2017\end{array}$ \\
\hline 8 & $\begin{array}{l}\text { Pseudomonas aeruginosa } \\
\text { GS9-119 and } \\
\text { Pseudomonas aeruginosa } \\
\text { DS10-129 }\end{array}$ & $\begin{array}{l}\text { Soybean oil } \\
\text { Safflower oil } \\
\text { Glycerol }\end{array}$ & $\begin{array}{l}4.31 \mathrm{~g} / \\
\mathrm{L} \\
2.98 \mathrm{~g} / \\
\mathrm{L} \\
1.77 \mathrm{~g} / \\
\mathrm{L}\end{array}$ & $\begin{array}{l}\text { Rahman et al., } \\
2002\end{array}$ \\
\hline 9 & $\begin{array}{l}\text { Pseudomonas aeruginosa } \\
\text { LBI }\end{array}$ & $\begin{array}{l}\text { Soybean oil } \\
\text { soap-stock }\end{array}$ & $\begin{array}{l}11.7 \mathrm{~g} / \\
\mathrm{L}\end{array}$ & $\begin{array}{l}\text { Nitschke et al., } \\
2009\end{array}$ \\
\hline 10 & $\begin{array}{l}\text { Pseudomonas aeruginosa } \\
\text { AB93066 }\end{array}$ & $\begin{array}{l}\text { Cooking oil } \\
\text { fume } \\
\text { condensates }\end{array}$ & $12.3 \mathrm{~g} / 1$ & Wu et al., 2019 \\
\hline 11 & $\begin{array}{l}\text { Pseudomonas aeruginosa } \\
\text { NCIM } 5514\end{array}$ & $\begin{array}{l}\text { Bushnell-Hass } \\
\text { medium with } \\
1 \% \text { crude oil }\end{array}$ & $\begin{array}{l}3.146 \\
\pm \\
0.087 \\
\mathrm{~g} / \mathrm{L}\end{array}$ & $\begin{array}{l}\text { Varjani and } \\
\text { Upasani, } 2019\end{array}$ \\
\hline 12 & Pseudomonas aeruginosa & $\begin{array}{l}\text { Kitchen waste } \\
\text { oil }\end{array}$ & $\begin{array}{l}2.47 \mathrm{~g} / \\
\mathrm{L}\end{array}$ & Chen et al., 2018 \\
\hline 13 & $\begin{array}{l}\text { Pseudomonas aeruginosa } \\
\text { estA }\end{array}$ & Crude glycerin & $\begin{array}{l}17.6 \mathrm{~g} / \\
\mathrm{L}\end{array}$ & $\begin{array}{l}\text { Dobler et al., } \\
2020\end{array}$ \\
\hline 14 & $\begin{array}{l}\text { Pseudomonas aeruginosa } \\
\# 112\end{array}$ & $\begin{array}{l}\text { Oil mill } \\
\text { wastewater }\end{array}$ & $5.1 \mathrm{~g} / \mathrm{L}$ & $\begin{array}{l}\text { Gudiña et al., } \\
2016\end{array}$ \\
\hline 15 & Pseudomonas aeruginosa & $\begin{array}{l}\text { Olive mill } \\
\text { (OMW) waste }\end{array}$ & $\begin{array}{l}29.5 \\
\mathrm{mg} / \mathrm{L}\end{array}$ & $\begin{array}{l}\text { Ramírez et al., } \\
2016\end{array}$ \\
\hline 16 & $\begin{array}{l}\text { Pseudomonas aeruginosa } \\
\text { AMB AS7 }\end{array}$ & $\begin{array}{l}\text { Coconut oil } \\
\text { sludge and oil } \\
\text { cake }\end{array}$ & $\begin{array}{l}5.53 \mathrm{~g} / \\
\mathrm{L}\end{array}$ & $\begin{array}{l}\text { Samykannu and } \\
\text { Achary, } 2017\end{array}$ \\
\hline 17 & $\begin{array}{l}\text { Pseudomonas aeruginosa } \\
\text { J4 }\end{array}$ & $\begin{array}{l}\text { Diesel } \\
\text { Kerosene }\end{array}$ & $\begin{array}{l}1300 \\
\mathrm{mg} / \mathrm{L} \\
709 \\
\mathrm{mg} / \mathrm{L}\end{array}$ & Wei et al., 2005 \\
\hline
\end{tabular}

using Pseudomonas aeruginosa OG1 in the presence of $10 \mathrm{~g} / \mathrm{L}$ ram horn peptone (RHP) and waste frying oil. Sood et al. (2020) have reported $19.22 \mathrm{~g} / \mathrm{L}$ rhamnolipid production in basal medium amended with rice bran oil and $21.77 \mathrm{~g} / \mathrm{L}$ rhamnolipid production in glycerol amended Luria Bertani (LB) medium using Pseudomonas aeruginosa CR1.

\subsection{Agro-industrial waste}

High content of lipids and carbohydrates are present in the agroindustrial waste hence it can be used to produce biosurfactants (Nitschke et al., 2004). Published literature shows production of rhamnolipid from various wastes such as oil mill wastewater (Gudiña et al., 2016), paneer whey (Patowary et al., 2016), barley pulp (Kaskatepe et al., 2017), orange peel (George and Jayachandran, 2008) and cassava waste (Costa et al., 2009; Tianran et al., 2019), etc. Rhamnolipid production from different agro-industrial and other wastes employing microorganisms is shown in Table 3. Joy et al. (2019) have reported $4.13 \pm 0.12 \mathrm{~g} / \mathrm{L}$ rhamnolipid production after $192 \mathrm{~h}$ using Achromobacter sp. PS1 from lingo-cellulosic residues (sugarcane bagasse, ricestraw and wheat-straw). Patowary et al. (2016) have reported production of $2.7 \mathrm{~g} / \mathrm{L}$ rhamnolipid using paneer whey as a source of carbon with help of Pseudomonas aeruginosa SR17 which was increased to $4.8 \mathrm{~g} /$ $\mathrm{L}$ when media was supplemented with $2 \%$ mineral salts and glucose.

\subsection{Other wastes}

Apart from above other wastes can also be used as a source of carbon for production of rhamnolipid such as bakery waste, shrimp shell waste, rice grains, fruit industrial waste, whey waste, dairy waste, etc. Patowary et al. (2018) have reported $11.56 \mathrm{~g} / \mathrm{L}$ rhamnolipid from bakery waste supplemented with mineral salt media using Pseudomonas aeruginosa PG1. Kadam and savant (2019) have isolated Pseudomonas stutzeri L1 from marine fishing port located in Mumbai and produced 4-6 g/ L rhamnolipid using shrimp shell waste. Borah et al. (2019) have produced $14.87 \mathrm{~g} / \mathrm{L}$ rhamnolipid by providing rice based distillers dried grains with solubles (rDDGS) as a carbon source to Pseudomonas aeruginosa SS14.

\section{Scale-up of rhamnolipid production}

Biosurfactants possesses important advantages over chemical

Table 3

Rhamnolipid production from different agro-industrial and other wastes employing microorganisms.

\begin{tabular}{|c|c|c|c|c|}
\hline $\begin{array}{l}\text { Sr. } \\
\text { No. }\end{array}$ & Organisms & Waste & Yield & Reference \\
\hline 1 & $\begin{array}{l}\text { Pseudomonas } \\
\text { aeruginosa SR17 }\end{array}$ & Paneer whey & $2.7 \mathrm{~g} / \mathrm{L}$ & $\begin{array}{l}\text { Patowary et al., } \\
2016\end{array}$ \\
\hline 2 & $\begin{array}{l}\text { Pseudomonas } \\
\text { azotoformans AJ15 }\end{array}$ & $\begin{array}{l}\text { Agro industrial } \\
\text { waste }\end{array}$ & $1.6 \mathrm{~g} / \mathrm{L}$ & $\begin{array}{l}\text { Das and Kumar, } \\
2018\end{array}$ \\
\hline \multirow[t]{3}{*}{3} & $\begin{array}{l}\text { Pseudomonas } \\
\text { aeruginosa ATCC } \\
9027\end{array}$ & Barley pulp & $9.3 \mathrm{~g} / \mathrm{L}$ & $\begin{array}{l}\text { Kaskatepe et al., } \\
2017\end{array}$ \\
\hline & $\begin{array}{l}\text { Pseudomonas } \\
\text { pachastrellae LOS20 }\end{array}$ & & $8.5 \mathrm{~g} / \mathrm{L}$ & \\
\hline & $\begin{array}{l}\text { Pseudomonas putida } \\
\text { IBS036 }\end{array}$ & & $6.7 \mathrm{~g} / \mathrm{L}$ & \\
\hline 4 & $\begin{array}{l}\text { Pseudomonas } \\
\text { aeruginosa MTCC } \\
2297\end{array}$ & Orange peel & $\begin{array}{l}9.18 \mathrm{~g} / \\
\mathrm{L}\end{array}$ & $\begin{array}{l}\text { George and } \\
\text { Jayachandran, } \\
2008\end{array}$ \\
\hline 5 & $\begin{array}{l}\text { Pseudomonas } \\
\text { aeruginosa }\end{array}$ & $\begin{array}{l}\text { Cassava } \\
\text { wastewater }\end{array}$ & $\begin{array}{l}660 \\
\mathrm{mg} / \mathrm{L}\end{array}$ & Costa et al., 2009 \\
\hline 6 & $\begin{array}{l}\text { Pseudomonas } \\
\text { aeruginosa ATCC } \\
10,145\end{array}$ & Cassava residues & $\begin{array}{l}18.28 \\
\mathrm{~g} / \mathrm{L}\end{array}$ & $\begin{array}{l}\text { Tianran et al., } \\
2019\end{array}$ \\
\hline 7 & $\begin{array}{l}\text { Achromobacter sp. } \\
\text { (PS1) }\end{array}$ & $\begin{array}{l}\text { Lignocellulosic } \\
\text { residues }\end{array}$ & $\begin{array}{l}4.13 \pm \\
0.12 \mathrm{~g} / \\
\mathrm{L}\end{array}$ & Joy et al., 2019 \\
\hline
\end{tabular}


surfactants. However, their production is still at laboratory level and needs further examination for industrial scale production. Good scale-up method used for production of rhamnolipid can decrease material cost as well as labour intensity (Amani, 2018). Production of rhamnolipid at large scale requires following steps (i) Microbial growth: rhamnolipid producing bacterial growth on petri plate containing growth media, (ii) Shake flask (small scale): bacterial growth used to test the production of rhamnolipid and study optimization production, (iii) Small scale fermenter (laboratory scale): bacterial culture than inoculated into the laboratory scale fermenter, and (iv) Large fermenter (pilot scale or industry level): used to produce huge amount of rhamnolipid developed at laboratory scale (Fedorenko et al., 2015; Li et al., 2015; Chong and Li, 2017; Heryani and Putra, 2017; Salea et al., 2017; Ye et al., 2018; Barros et al., 2019). This scale-up process is necessary for large scale product manufacturing, since every process varies in the condition which affects the production.

Gong et al. (2020) have performed scale-up for production of rhamnolipid using air pressure pulsation solid-state fermentation (APPSSF) and achieved 39.8 $\mathrm{g} / \mathrm{L}$ rhamnolipid production in a 30L APP-SSF fermenter using 10\% Pseudomonas aeruginosa SKY as inoculum, and incubation was performed at $37{ }^{\circ} \mathrm{C}$ for $168 \mathrm{~h}$ at $50 \mathrm{rpm}$. Rhamnolipid produced by this method at large-scale contains high productivity, low cost and low impurities of production. Amani (2018) has performed rhamnolipid production experiment using $2.5 \mathrm{~L}$ and $20 \mathrm{~L}$ bioreactor using Pseudomonas aeruginosa MM1011. Maximum production of rhamnolipid $(8.3 \mathrm{~g} / \mathrm{L})$ was reported in $20 \mathrm{~L}$ bioreactor which was $10 \%$ better than in $2.5 \mathrm{~L}$ bioreactor after 7 days at $37^{\circ} \mathrm{C}$.

\section{Applications}

Rhamnolipids have found various applications in bioremediation of polluted environments (hydrocarbon, heavy metals, pesticides, dyes and plastics etc), microbial enhanced oil recovery, agricultural, beverages, cosmetics, foods, pharmaceuticals (Singh et al., 2009; Jiménez-Peñalver et al., 2019; Rajmohan et al., 2019; Biselli et al., 2020; Shi et al., 2020; Varjani et al., 2020b). Some rhamnolipids contain antifungal, antiviral and antibacterial properties which make them useful for fighting against infections and diseases (Souza et al., 2017).

\subsection{Bioremediation}

Biosurfactants are used to intensify the bioremediation process (Varjani et al., 2017; Staninska-Pięta et al., 2019). Rhamnolipid have been used to remediate heavy metals, dyes, pesticides, hydrocarbons, oil spills and contaminated soils, etc. (Varjani, 2017; Patel et al., 2018; Lee and Kim, 2019; Varjani et al., 2019; Wei et al., 2020; Kumar et al., 2020). Rhamnolipids help in remediation process by emulsifying or solubilizing hydrocarbons and modifying bacterial cell surface properties for intensification of interfacial uptake of hydrocarbons (Liu et al., 2018). Bhosale et al. (2019) have reported $92.72 \%$ decolorization of methyl violet dye using rhamnolipid functionalized iron oxide nanoparticles (RL@IONPs) as photocatalyst (8 $\mathrm{mg}$ ) and sodium dodecyl sulfate (SDS) as absorbent (0.12 mg). Rhamnolipid was produced by Pseudomonas aeruginosa ATCC 9027 using $10 \mathrm{~mL}$ culture medium. Olasanmi and Thring (2020) have used rhamnolipid at $500 \mathrm{mg} / \mathrm{L}$ concentration for reduction of petroleum hydrocarbons. The maximum petroleum hydrocarbons reduction rate for total petroleum hydrocarbon (TPH) fractions F2 (C10-C16), F3 (C16-C34) and F4 (C34-C50) was $58.5 \%, 48.4 \%, 63.5 \%$ and $59.8 \%$, respectively for petroleum contaminated soil. J. Chen et al., 2017; W. Chen et al., 2017 have reported $80.21 \%, 47.85 \%, 63.54 \%$ and $86.87 \%$ removal of $\mathrm{Cu}, \mathrm{Cr}, \mathrm{Pb}$ and $\mathrm{Cd}$, respectively using $0.8 \%$ rhamnolipid for experiment of $12 \mathrm{~h}$ at $\mathrm{pH}$ 7.0. Gaur et al. (2019a) produced $1.6 \mathrm{~g} / \mathrm{L}$ rhamnolipid using Lysinibacillus sphaericus IITR51. Rhamnolipid at concentration of $90 \mathrm{mg} / \mathrm{L}$ was reported for higher dissolution of $\gamma$-hexachlorocyclohexane, $\beta$-endosulfan and $\alpha$-endosulfan up to 1.8, 2.9 and 7.2 folds, respectively than at other concentrations i.e. $45 \mathrm{mg} / \mathrm{L}, 60 \mathrm{mg} / \mathrm{L}, 75 \mathrm{mg} / \mathrm{L}, 90 \mathrm{mg} / \mathrm{L}$, and $105 \mathrm{mg} / \mathrm{L}$. They have reported application of rhamnolipid for enhanced dissolution and increased bioavailability of pollutants.

\subsection{Microbial enhanced oil recovery}

Microbial enhanced oil recovery (MEOR) has been used as a tertiary process when primary and secondary treatment processes are no longer able to recover oil (Varjani and Upasani, 2016a). Rhamnolipids (biosurfactants) are key elements in oil recovery process due to their tolerant capability to withstand extreme environmental conditions, nontoxic and eco-friendly nature (Varjani and Upasani, 2016b; Das and Kumar, 2019; Elakkiya et al., 2020; Wei et al., 2020). Elakkiya et al. (2020) produced rhamnolipid $(0.34 \mathrm{mg} / \mathrm{mL})$ from cassava solid waste using Pseudomonas aerugimosa TEN01 and achieved highest oil recovery $14.28 \%$ using biosurfactant based silver nanoparticle which was similar to chemically produced silver nanoparticle. Haloi et al. (2020) have used Pseudomonas sp. TMB2 (KX661384) for production of $2.8 \pm 0.5 \mathrm{~g} / \mathrm{L}$ rhamnolipid and reported overall $27.11 \%$ oil recovery efficiency with an additional $16.7 \%$ recovery after secondary brine flooding from rock plug NH1. Câmara et al. (2019) have produced rhamnolipid using Pseudomonas aeruginosa for oil recovery. They have reported $11.91 \pm 0.39 \%$ improved advanced recovery by microorganisms from a total recovery factor of $50.45 \pm 0.79 \%$.

\subsection{Medical applications}

Rhamnolipid possesses antimicrobial properties and can be used as biopesticides. Rhamnolipids are more effective against gram-positive bacteria than gram-negative bacteria due to presence of outer membrane in gram-negative bacteria which works as a protective layer (Murugan et al., 2018; Naughton et al., 2019). Literatures are available that shows various applications of rhamnolipid biosurfactant in the field of biomedicine as anticancer, antimicrobial, antitumor, antiviral, immune modulators and wound treating agent (J. Chen et al., 2017; W. Chen et al., 2017; Kumar and Das, 2018). Yi et al. (2019) have prepared nanoparticles of rhamnolipid using flax seed oil and loaded them with model drug pheophorbide a ( $\mathrm{Pba}$ ). They have used photodynamic in vivo therapy and rhamnolipid nanoparticle to achieve complete suppression of tumor. J. Chen et al., 2017; W. Chen et al., 2017 have reported antimicrobial activity of rhamnolipid mixture produced by $P$. aeruginosa sp.

Niaz et al. (2019) have performed inhibitory activity assay with rhamnolipid at minimal inhibitory concentrations (MICs) at 5, 10, 50 and $1000 \mu \mathrm{g} / \mathrm{mL}$ against $P$. aeruginosa, S. aureus, E. coli and L. monocytogenes, respectively. Results propose that all foodborne pathogens used in study were sensitive to rhamnolipid at very low concentrations except L. monocytogenes. They have reported $80 \%$ decrease in generation of biofilm biomass when treated with nisinloaded rhamnosome nano-vesicles (RSNVs). Gaur et al. (2019b) have reported production of rhamnolipid by Lysinibacillus sphaericus IITR51. It showed antibacterial activity against pathogenic bacteria such as Bacillus subtilis MTCC 441, Aeromonas hydrophilia MTCC 1143, Pseudomonas aeruginosa MTCC 424, Vibrio cholera MTCC 3904, Escherichia coli MTCC 723 and Klebsiella pneumonia MTCC 109. Gaur et al. (2020) have produced 2.5 and $1.8 \mathrm{~g} / \mathrm{L}$ rhamnolipid using Planococcus rifietoensis IITR53 and Planococcus halotolerans IITR55 and reported antibacterial activity against Yersinia enterocolitica MTCC 859, Vibrio cholerae MTCC 3904, Clostridium perfringens MTCC 450, Streptococcus mutans MTCC 497, Salmonella typhimurium MTCC 98 and Streptococcus oralis MTCC 2696.

\subsection{Other applications}

Rhamnolipid is a low foaming agent. Its foaming capability can be increased by the combination with alpha olefin sulfonate (AOS) or 
sodium lauryl ether sulfate (SLES). Due to its low foaming capability rhamnolipid based liquid detergents can be used for washing machines as laundry detergents (Jadhav et al., 2019). Around 5,00,000 tons of emulsifiers are produced each year for food industry applications (Gudiña and Rodrigues, 2019). Rhamnolipids are used in food industries as wetting or foaming agents/stabilizers (to support stability of food ingredients) and emulsifiers (for texture and consistency of food), thereby it helps in increasing shelf life of food products.

\section{Research needs and future directions}

Bio-based surfactant production from waste streams would be a favourable way for resource recovery. However, developments need to be carried out for enabling economically \& ecologically feasible production and recovery technologies. Rhamnolipid biosurfactant can be produced by various microorganisms using different industrial wastes/ raw materials; however, it requires further examination for scale-up to produce rhamnolipid. Many researchers have used Pseudomonas sp. for production of rhamnolipid (Li, 2017; Varjani and Upasani, 2016c, 2019; Das and Kumar, 2018). Rhamnolipid has various industrial applications but it is limited due to its high cost for production (Benrebah et al., 2007). Different microorganisms can be used to produce biosurfactants with different structures and characteristics having different application efficiency (Varjani and Upasani, 2017a; Dell'Anno et al., 2018). Carbon sources and fermentation conditions can affect yield of rhamnolipid ( $\mathrm{Li}$, 2017). There are many bottlenecks that are required to be resolved to support biosurfactant production and recovery from waste streams as an advantageous option for resource recovery. After production, recovery would certainly add to the total cost for biosurfactant production using waste streams. It is necessary to recover maximum surfactant produced from waste streams. For this care should be taken in order not to have too much cost which would not be feasible economically. The challenge would be selection of cost-effective method for recovery which would lead to maximum biosurfactant recovery at minimal cost.

- Future research should examine various factors that may affect rhamnolipid production.

- For application of biosurfactants in remediation of polluted sites or enhanced oil recovery in depth efficiency of rhamnolipid type biosurfactants should be studied. Application of rhamnolipid should be studied under extreme environmental conditions.

- The quality and production yield of rhamnolipid can be improved using genetic engineering.

- New technologies and strategies are required to improve yield and decrease production costs. There is a need for in depth cost-benefit analysis for biosurfactant recovery methods.

- Rhamnolipid production using wastes as raw materials need to be performed at large scale to support waste valorisation concept.

\section{Conclusions}

Production of bio-based rhamnolipids from waste streams is gaining interest of researchers. Rhamnolipids have found applications in various industries such as petroleum, agriculture, cosmetics and medicine. Systematic research is required to be performed to study the effect of operational conditions for rhamnolipids production and recovery from wastes. There is a need for in depth cost-benefit analysis for recovery of biosurfactants. Large scale production and purification of rhamnolipids increase cost which can be reduced using waste materials for its production. It is opined that employing wastes as resource would make the process more environmental friendly and cost effective.

\section{Declaration of Competing Interest}

The authors declare that they have no known competing financial interests or personal relationships that could have appeared to influence the work reported in this paper.

\section{Acknowledgement}

Authors are grateful to the management of Gujarat Pollution Control Board, Gandhinagar, Gujarat, India for providing necessary facilities to perform literature review presented in this paper.

\section{References}

Amani, H., 2018. Application of a Dynamic Method for the Volumetric Mass Transfer Coefficient Determination in the Scale-Up of Rhamnolipid Biosurfactant Production. J. Surfactants Deterg. 21 (6), 827-833.

Barros, A., Pereira, H., Campos, J., Marques, A., Varela, J., Silva, J., 2019. Heterotrophy as a tool to overcome the long and costly autotrophic scale-up process for large scale production of microalgae. Sci. Rep. 9, 13935. https://doi.org/10.1038/s41598-01950206-Z.

Benrebah, F., Prevost, D., Yezza, A., Tyagi, R., 2007. Agro-industrial waste materials and wastewater sludge for rhizobial inoculant production: A review. Bioresour. Technol. 98 (18), 3535-3546.

Bhosale, S.S., Rohiwal, S.S., Chaudhary, L.S., Pawar, K.D., Patil, P.S., Tiwari, A.P., 2019. Photocatalytic decolorization of methyl violet dye using Rhamnolipid biosurfactant modified iron oxide nanoparticles for wastewater treatment. J. Mater. Sci. Mater. Electron. 30, 4590-4598.

Biselli, A., Willenbrink, A.L., Leipnitz, M., Jupke, A., 2020. Development, evaluation, and optimisation of downstream process concepts for rhamnolipids and 3-(3hydroxyalkanoyloxy) alkanoic acids. Separation Purification Technol. 250, 117031 https://doi.org/10.1016/j.seppur.2020.117031.

Borah, S.N., Sen, S., Goswami, L., Bora, A., Pakshirajan, K., Deka, S., 2019. Rice based distillers dried grains with solubles as a low cost substrate for the production of a novel rhamnolipid biosurfactant having anti-biofilm activity against Candida tropicalis. Colloid. Surface. B: Biointerfaces. 182, 110358 https://doi.org/10.1016/j. colsurfb.2019.110358.

Câmara, J.M.D.A., Sousa, M.A.S.B., Barros Neto, E.L., Oliveira, M.C.A., 2019. Application of rhamnolipid biosurfactant produced by Pseudomonas aeruginosa in microbialenhanced oil recovery (MEOR). J. Petrol. Explor. Prod. Technol. 9, 2333-2341.

Chen, W., Qu, Y., Xu, Z., He, F., Chen, Z., Huang, S., Li, Y., 2017b. Heavy metal (Cu, Cd, $\mathrm{Pb}, \mathrm{Cr}$ ) washing from river sediment using biosurfactant rhamnolipid. Environ. Sci. Pollut. Res. 24 (19), 16344-16350.

Chen, C., Sun, N., Li, D., Long, S., Tang, X., Xiao, G., Wang, L., 2018. Optimization and characterization of biosurfactant production from kitchen waste oil using Pseudomonas aeruginosa. Environ. Sci. Pollut. Res. 25 (15), 14934-14943.

Chen, J., Wu, Q., Hua, Y., Chen, J., Zhang, H., Wang, H., 2017a. Potential applications of biosurfactant rhamnolipids in agriculture and biomedicine. Appl. Microbiol. Biotechnol. 101 (23-24), 8309-8319.

Chong, H., Li, Q., 2017. Microbial production of rhamnolipids: opportunities, challenges and strategies. Microb. Cell Fact. 16, 137. https://doi.org/10.1186/s12934-0170753-2.

Conceição, K.S., de Alencar Almeida, M., Sawoniuk, I.C., Marques, G.D., de Sousa FariaTischer, P.C., Tischer, C.A., Vignoli, J.A., Camilios-Neto, D., 2020. Rhamnolipid production by Pseudomonas aeruginosa grown on membranes of bacterial cellulose supplemented with corn bran water extract. Environ. Sci. Pollut. Res., doi: https:// doi.org/10.1007/s11356-020-09315-w.

Costa, S.G.V.A.O., Lépine, F., Milot, S., Déziel, E., Nitschke, M., Contiero, J., 2009. Cassava wastewater as a substrate for the simultaneous production of rhamnolipids and polyhydroxyalkanoates by Pseudomonas aeruginosa. J. Ind. Microbiol. Biotechnol. 36 (8), 1063-1072.

Das, A.J., Kumar, R., 2018. Utilization of agro-industrial waste for biosurfactant production under submerged fermentation and its application in oil recovery from sand matrix. Bioresour. Technol. 260, 233-240.

Das, A.J., Kumar, R., 2019. Production of biosurfactant from agro-industrial waste by Bacillus safensis $\mathrm{J} 2$ and exploring its oil recovery efficiency and role in restoration of diesel contaminated soil. Environ. Technol. Innovation 16, 100450. https://doi.org/ 10.1016/j.eti.2019.100450.

Deepika, K.V., Kalam, S., Sridhar, P.R., Podile, A.R., Bramhachari, P.V., 2016. Optimization of rhamnolipid biosurfactant production by mangrove sediment bacterium Pseudomonas aeruginosa KVD-HR42 using response surface methodology. Biocatal. Agric. biotechnol. 5, 38-47.

Delegan, Y., Sargsyan, A., Hovhannisyan, N., Babayan, B., Petrikov, K., Vainstein, M., 2020. Analysis of genome sequence and trehalose lipid production peculiarities of the thermotolerant Gordonia strain. J. Basic Microbiol. 60 (1), 14-21.

Dell'Anno, F., Sansone, C., Ianora, A., Dell'Anno, A., 2018. Biosurfactant-induced remediation of contaminated marine sediments: Current knowledge and future perspectives. Mar. Environ. Res. 137, 196-205.

Díaz De Rienzo, M.A., Kamalanathan, I.D., Martin, P.J., 2016. Comparative study of the production of rhamnolipid biosurfactants by $B$. thailandensis E264 and P. aeruginosa ATCC 9027 using foam fractionation. Process Biochem. 51 (7), 820-827.

Dobler, L., Ferraz, H.C., Araujo de Castilho, L.V., Sangenito, L.S., Pasqualino, I.P., Souza dos Santos, A.L., Neves, B.C., Oliveira, R.R., Freire, D.M.G., Almeida, R.V., 2020. Environmentally friendly rhamnolipid production for petroleum remediation. Chemosphere 252, 126349. https://doi.org/10.1016/j.chemosphere.2020.126349.

Dolman, B.M., Kaisermann, C., Martin, P.J., Winterburn, J.B., 2017. Integrated sophorolipid production and gravity separation. Process Biochem. 54, 162-171. 
Drakontis, C.E., Amin, S., 2020. Biosurfactants: Formulations, Properties, and Applications. Curr. Opin. Colloid Interface. Sci. 48, 77-90.

Elakkiya, V.T., SureshKumar, P., Alharbi, N.S., Kadaikunnan, S., Khaled, J.M., Govindarajan, M., 2020. Swift production of rhamnolipid biosurfactant, biopolymer and synthesis of biosurfactant-wrapped silver nanoparticles and its enhanced oil recovery. Saudi J. Biol. Sci. 27 (7), 1892-1899.

Elshikh, M., Moya-Ramírez, I., Moens, H., Roelants, S., Soetaert, W., Marchant, R., Banat, I.M., 2017. Rhamnolipids and lactonicsophorolipids: natural antimicrobial surfactants for oral hygiene. J. Appl. Microbiol. 123 (5), 1111-1123.

Fedorenko, V., Genilloud, O., Horbal, L., Marcone, G.L., Marinelli, F., Paitan, Y., Ron, E. Z., 2015. Antibacterial Discovery and Development: From Gene to Product and Back. Biomed Res. Int. 1-16 https://doi.org/10.1155/2015/591349.

Gámez, O.R., Rodríguez, A.A., Cadre, J.V., Gómez, J.G.C., 2017. Screening and Characterization of Biosurfactant-Producing Bacteria Isolated from Contaminated Soils with Oily Wastes. J. Environ. Treat. Tech. 5 (1), 5-11.

Gaur, V.K., Bajaj, A., Regar, R.K., Kamthan, M., Jha, R.R., Srivastava, J.K., Manickam, N., 2019a. Rhamnolipid from a Lysinibacillus sphaericus strain IITR51 and its potential application for dissolution of hydrophobic pesticides. Bioresour. Technol. 272, 19-25.

Gaur, V.K., Regar, R.K., Dhiman, N., Dautam, K., Srivastava, J.L., Patnaik, S., Kamthan, M., Manickam, N., 2019b. Biosynthesis and characterization of sophorolipid biosurfactant by Candida spp.: Application as food emulsifier and antibacterial agent. Bioresour. Biotechnol. 285, 121314 https://doi.org/10.1016/j. biortech.2019.121314.

Gaur, V.K., Tripathi, V., Gupta, P., Dhiman, N., Regar, R.K., Gautam, K., Srivastava, J.K., Patnaik, S., Patel, D.K., Manickam, N., 2020. Rhamnolipids from Planococcus spp. and their mechanism of action against pathogenic bacteria. Bioresour. Technol. 307, 123206 https://doi.org/10.1016/j.biortech.2020.123206.

George, S., Jayachandran, K., 2008. Analysis of Rhamnolipid Biosurfactants Produced Through Submerged Fermentation Using Orange Fruit Peelings as Sole Carbon Source. Appl. Biochem. Biotechnol. 158 (3), 694-705.

Gong, Z., He, Q., Che, C., Liu, J., Yang, G., 2020. Optimization and scale-up of the production of rhamnolipid by Pseudomonas aeruginosa in solid-state fermentation using high-density polyurethane foam as an inert support. Bioprocess Biosyst. Eng. 43, 385-392.

Gudiña, E.J., Rodrigues, A.I., de Freitas, V., Azevedo, Z., Teixeira, J.A., Rodrigues, L.R., 2016. Valorization of agro-industrial wastes towards the production of rhamnolipids. Bioresour. Technol. 212, 144-150.

Gudiña, E.J., Rodrigues, L.R., 2019. Research and Production of Biosurfactants for the Food Industry. Bioprocess. Biomolecules Prod. 125-143 https://doi.org/10.1002/ 9781119434436.ch6.

Haloi, S., Sarmah, S., Gogoi, S.B., Medhi, T., 2020. Characterization of Pseudomonas sp. TMB2 produced rhamnolipids for ex-situ microbial enhanced oil recovery. 3. Biotech. 10 (3), 120. https://doi.org/10.1007/s13205-020-2094-9.

He, C., Dong, W., Li, J., Li, Y., Huang, C., Ma, Y., 2017. Characterization of rhamnolipid biosurfactants produced by recombinant Pseudomonas aeruginosa strain DAB with removal of crude oil. Biotechnol. Lett. 39, 1381-1388.

He, S., Ni, Y., Lu, L., Chai, Q., Yu, T., Shen, Z., Yang, C., 2020. Simultaneous degradation of n-hexane and production of biosurfactants by Pseudomonas sp. strain NEE2 isolated from oil-contaminated soils. Chemosphere 242, 125237. https://doi.org/ 10.1016/j.chemosphere.2019.125237.

Henkel, M., Geissler, M., Weggenmann, F., Hausmann, R., 2017. Production of microbial biosurfactants: Status quo of rhamnolipid and surfactin towards large-scale production. Biotechnol. J. 12 (7), 1600561. https://doi.org/10.1002/ biot. 201600561.

Heryani, H., Putra, M.D., 2017. Dataset on potential large scale production of biosurfactant using Bacillus Sp. Data Brief. 13, 196-201.

Huang, T.T., Wages, J.M., 2016. New-to-nature sophorose analog: a potent inducer for gene expression in Trichoderma reesei. Enzyme Microb. Technol. 85, 44-50.

Jadhav, J.V., Anbu, P., Yadav, S., Pratap, A.P., Kale, S.B., 2019. Sunflower Acid Oil-Based Production of Rhamnolipid Using Pseudomonas aeruginosa and Its Application in Liquid Detergents. J. Surfactants Deterg. 22 (3), 463-476.

Jahan, R., Bodratti, A.M., Tsianou, M., Alexandridis, P., 2019. Biosurfactants, natural alternatives to synthetic surfactants: Physicochemical properties and applications. Adv. Colloid Interface Sci. 275, 102061 https://doi.org/10.1016/j.cis.2019.102061.

Jiang, J., Zu, Y., Li, X., Meng, Q., Long, X., 2019. Recent progress towards industrial rhamnolipids fermentation: process optimization and foam control. Bioresour. Technol. 298, 122394 https://doi.org/10.1016/j.biortech.2019.122394.

Jiménez-Peñalver, P., Rodríguez, A., Daverey, A., Font, X., Gea, T., 2019. Use of wastes for sophorolipids production as a transition to circular economy: state of the art and perspectives. Rev. Environ. Sci. Biotechnol. 18, 413-435.

Joy, S., Rahman, P.K.S.M., Khare, S.K., Sharma, S., 2019. Production and characterization of glycolipid biosurfactant from Achromobacter sp. (PS1) isolate using one-factor-at-a-time (OFAT) approach with feasible utilization of ammoniasoaked lignocellulosic pretreated residues. Bioprocess Biosyst. Eng. 42, 1301-1315.

Kadam, D., Savant, D., 2019. Biosurfactant production from shrimp shell waste by Pseudomonas stutzeri. Indian J. Mar. Sci. 48 (9), 1411-1418.

Kaskatepe, B., Yildiz, S., Gumustas, M., Ozkan, S.A., 2017. Rhamnolipid Production by Pseudomonas putida IBS036 and Pseudomonas pachastrellae LOS20 with using pulps. Curr. Pharm. Anal. 13 (2), 138-144.

Kaur, G., Wang, H., To, M.H., Roelants, S.L.K.W., Soetaert, W., Lin, C.S.K., 2019. Efficient sophorolipids production using food waste. J. Clean. Prod. 232, 1-11.

Kim, S.K., Park, S.J., Li, X.H., Choi, Y.S., Im, D.S., Lee, J.H., 2018. Bacterial ornithine lipid, a surrogate membrane lipid under phosphate-limiting conditions, plays important roles in bacterial persistence and interaction with host. Environ. Microbial. 20 (11), 3992-4008.
Kourmentza, C., Koutra, E., Venetsaneas, N., Kornaros, M., 2017. Integrated Biorefinery Approach for the Valorization of Olive Mill Waste Streams Towards Sustainable Biofuels and Bio-Based Products. Microbial Applications. 1, 211-238.

Kumar, N.M., Sudha, M.C., Damodharam, T., Varjani, S., 2020. Micro-pollutants in surface water: Impacts on aquatic environment and treatment technologies. In: Varjani, S., Pandey, A., Tyagi, R.D., Ngo, H.H., Larroche, C. (Eds.), Emerging Organic Micro-pollutants. Elsevier, Amsterdam, Netherlands, pp. 41-61.

Kumar, R., Das, A.J., 2018. Application of Rhamnolipids in Medical Sciences. In: Rhamnolipid Biosurfactant. Springer, Singapore, pp. 79-87, doi: https://doi.org/ 10.1007/978-981-13-1289-2_7.

Lee, A., Kim, K., 2019. Removal of Heavy Metals Using Rhamnolipid Biosurfactant on Manganese Nodules. Water Air Soil Pollut. 230 (11), 258. https://doi.org/10.1007/ s11270-019-4319-2.

Lewenza, S., Falsafi, R., Bains, M., Rohs, P., Stupak, J., Sprott, G.D., Hancock, R.E.W., 2011. The olsA gene mediates the synthesis of an ornithine lipid in Pseudomonas aeruginosa during growth under phosphate-limiting conditions, but is not involved in antimicrobial peptide susceptibility. FEMS Microbiol. Lett. 320 (2), 95-102.

Li, J., Jaitzig, J., Lu, P., Süssmuth, R.D., Neubauer, P., 2015. Scale-up bioprocess development for production of the antibiotic valinomycin in Escherichia coli based on consistent fed-batch cultivations. Microb. Cell Fact. 14, 83. https://doi.org/ 10.1186/s12934-015-0272-y.

Li, Q., 2017. Rhamnolipid synthesis and production with diverse resources. Front. Chem. Sci. Eng. 11, 27-36.

Liu, G., Zhong, H., Yang, X., Liu, Y., Shao, B., Liu, Z., 2018. Advances in applications of rhamnolipids biosurfactant in environmental remediation: a review. Biotechnol. Bioeng. 115 (4), 796-814.

Lotfabad, T.B., Ebadipour, N., Roostaazad, R., Partovi, M., Bahmaei, M., 2017. Two schemes for production of biosurfactant from Pseudomonas aeruginosa MR01: Applying residues from soybean oil industry and silica sol-gel immobilized cells. Colloid Surf.B: Biointerfaces. 152, 159-168.

Marcelino, P.R.F., Peres, G.F.D., Terán-Hilares, R., Pagnocca, F.C., Rosa, C.A., Lacerda, T. M., dos Santos, J.C., da Silva, S.S., 2019. Biosurfactants production by yeasts using sugarcane bagasse hemicellulosic hydrolysate as new sustainable alternative for lignocellulosic biorefineries. Ind. Crop. Prod. 129, 212-223.

Mei, Y., Huang, P., Liu, Y., He, W., Fang, W.W., 2016. Cold stress promoting a psychrotolerant bacterium Pseudomonas fragi P121 producing trehaloase. World J. Microbiol. Biotechnol. 32, 134. https://doi.org/10.1007/s11274-016-2097-1.

Mishra, B., Varjani, S., Kumar, G., Awasthi, M.K., Awasthi, S.K., Sindhu, R., Binod, P., Rene, E.R., Zhang, Z., 2020. Microbial approaches for remediation of pollutants: Innovations, future outlook, and challenges. Energy Environ. 1-30 https://doi.org/ 10.1177/0958305X19896781.

Moshtagh, B., Hawboldt, K., Zhang, B., 2018. Optimization of biosurfactant production by Bacillus Subtilis N3-1P using the brewery waste as the carbon source. Environ. Technol. 40 (25), 3371-3380.

Mostafa, N.A., Tayeb, A.M., Mohamed, O.A., Farouq, R., 2019. Biodegradation of Petroleum Oil Effluents and Production of Biosurfactants: Effect of Initial Oil Concentration. J. Surfactants Deterg. 22 (2), 385-394.

Müller, M.M., Hausmann, R., 2011. Regulatory and metabolic network of rhamnolipid biosynthesis: Traditional and advanced engineering towards biotechnological production. Appl. Microbiol. Biotechnol. 91 (2), 251-264.

Murugan, T., Murugan, M., Albino, W.J., 2018. Rhamnolipid Biosurfactants produced by Pseudomonas sp. MK5 and its efficacy on Pharmaceutical Application. Res. J. Pharm. Technol. 10 (8), 2645-2649.

Naughton, P.J., Marchant, R., Naughton, V., Banat, I.M., 2019. Microbial Biosurfactants: Current trends and applications in Agricultural and Biomedical industries. J. Appl. Microbiol. 127 (1), 12-28.

Niaz, T., Shabbir, S., Noor, T., Imran, M., 2019. Antimicrobial and antibiofilm potential of bacteriocin loaded nano-vesicles functionalized with rhamnolipids against foodborne pathogens. LWT. 116, 108583 https://doi.org/10.1016/j. lwt.2019.108583.

Nitschke, M., Costa, S.G.V.A.O., Contiero, J., 2009. Structure and Applications of a Rhamnolipid Surfactant Produced in Soybean Oil Waste. Appl. Biochem. Biotechnol. 160 (7), 2066-2074.

Nitschke, M., Ferraz, C., Pastore, G.M., 2004. Selection of microorganisms for biosurfactant production using agroindustrial wastes. Brazilian J. Microbiol. 35 (1-2), 81-85.

Olasanmi, I.O., Thring, R.W., 2020. Evaluating Rhamnolipid-Enhanced Washing as a First Step in Remediation of Petroleum-Contaminated Soils and Drill Cuttings. J. Adv. Res. 21, 79-90.

Özdal, M., Gürkök, S., Özdal, Ö.G., Kurbanoğlu, E.B., 2017. Rhamnolipid production by Pseudomonas aeruginosa OG1 using waste frying oil and ram horn peptone. 1833, 020102, doi: 10.1063/1.4981750.

Patel, S., Homaei, A., Patil, S., Daverey, A., 2018. Microbial biosurfactants for oil spill remediation: pitfalls and potentials. Appl. Microbiol. Biotechnol. 103, 27-37.

Patil, H.I., Pratap, A.P., 2018. Production and Quantitative Analysis of Trehalose Lipid Biosurfactants Using High-Performance Liquid Chromatography. J. Surfactant. Detergent. 21 (4), 553-564.

Patowary, K., Das, M., Patowary, R., Kalita, M.C., Deka, S., 2018. Recycling of Bakery Waste as an Alternative Carbon Source for Rhamnolipid Biosurfactant Production. J. Surfactants Deterg. 22 (2), 373-384.

Patowary, R., Patowary, K., Kalita, M.C., Deka, S., 2016. Utilization of Paneer Whey Waste for Cost-Effective Production of Rhamnolipid Biosurfactant. Appl. Biochem. Biotechnol. 180 (3), 383-399.

Pérez-Armendáriz, B., Cal-y-Mayor-Luna, C., El-Kassis, E.G., Ortega-Martínez, L.D., 2019. Use of waste canola oil as a low-cost substrate for rhamnolipid production 
using Pseudomonas aeruginosa. AMB Express. 9, 61, doi: 10.1186/s13568-0190784-7.

Radzuan, M.N., Banat, I.M., Winterburn, J., 2017. Production and characterization of rhamnolipid using palm oil agricultural refinery waste. Bioresour. Technol. 225, 99-105.

Rahman, K.S.M., Rahman, T.J., McClean, S., Marchant, R., Banat, I.M., 2002. Rhamnolipid Biosurfactant Production by Strains of Pseudomonas aeruginosa Using Low-Cost Raw Materials. Biotechnol. Progress. 18 (6), 1277-1281.

Rajmohan, K.S., Ramya, C., Varjani, S., 2019. Plastic pollutants: Waste management for pollution control and abatement. Curr. Opinion Environ. Sci. Health. 12, 72-84.

Rajmohan, K.S., Ramya, C., Varjani, S., 2020. A Review on occurrence of pesticides in environment and current technologies for their remediation and management. Indian J. Microbiol. 60, 125-138.

Ramírez, I.M., Vaz, D.A., Banat, I.M., Marchant, R., Alameda, E.J., Román, M.G., 2016. Hydrolysis of olive mill waste to enhance rhamnolipids and surfactin production. Bioresour. Technol. 205, 1-6.

Renterghem, L.V., Roelants, S.L.K.W., Baccile, N., Uyttersprot, K., Taelman, M.C., Everaert, B., Mincke, S., Ledegen, S., Debrouwer, S., Scholtens, K., Stevens, C., Soetaert, W., 2018. From lab to market: An integrated bioprocess design approach for new-to-nature biosurfactants produced by Starmerella bombicola. Biotechnol. Bioeng. 115 (5), 1195-1206.

Roy, A., 2017. Review on the biosurfactants: properties, types and its applications. J. Fundam. Renew. Energy Appl 8, 1-14.

Salea, R., Veriansyah, B., Tjandrawinata, R.R., 2017. Optimization and scale-up process for supercritical fluids extraction of ginger oil from Zingiber officinale var. Amarum. J. Supercrit. Fluids. 120, 285-294.

Samykannu, M., Achary, A., 2017. Utilization of Agro-Industry Residue for Rhamnolipid Production by P. aeruginosa AMB AS7 and Its Application in Chromium Removal. Appl. Biochem. Biotechnol. 183, 70-90.

Satpute, S.K., Płaza, G.A., Banpurkar, A.G., 2017. Biosurfactants Production from Renewable Natural Resources: Example of Innovativeand Smart Technology in Circular Bioeconomy. Manage. Sy. Prod. Eng. 25, 46-54.

Shah, M.U.H., Sivapragasam, M., Moniruzzaman, M., Talukder, M.D.M.R., Yusup, S.B., Goto, M., 2017. Production of sophorolipids by Starmerella bombicola yeast using new hydrophobic substrates. Biochem. Eng. J. 127, 60-67.

Shi, Z., Wang, C., Zhao, Y., 2020. Effects of surfactants on the fractionation, vermiaccumulation, and removal of fluoranthene by earthworms in soil. Chemosphere 250, 126332. https://doi.org/10.1016/j.chemosphere.2020.126332.

Singh, P., Patil, Y., Rale, V., 2018. Biosurfactant Production: Emerging Trends and Promising Strategies. J. Appl. Microbiol. 126 (1), 2-13.

Singh, P.B., Sharma, S., Saini, H.S., Chadha, B.S., 2009. Biosurfactant production by Pseudomonas sp. and its role in aqueous phase partitioning and biodegradation of chlorpyrifos. Lett. Appl. Microbiol. 49, 378-383. https://doi.org/10.1111/j.1472765X.2009.02672.x.

Sood, U., Singh, D.N., Hira, P., Lee, J.K., Kalia, V.C., Lal, R., Shakarad, M., 2020. Rapid and solitary production of mono-rhamnolipid biosurfactant and biofilm inhibiting pyocyanin by a taxonomic outlier Pseudomonas aeruginosa strain CR1. J. Biotechnol. 307, 98-106.

Souza, K.S.T., Gudiña, E.J., Azevedo, Z., de Freitas, V., Schwan, R.F., Rodrigues, L.R., Dias, D.R., Teixeira, J.A., 2017. New glycolipid biosurfactants produced by the yeast strain Wickerhamomyces anomalus CCMA 0358. Colloid Surface B: Biointerfaces. 154, 373-382.

Staninska-Pięta, J., Piotrowska-Cyplik, A., Juzwa, W., Zgoła-Grześkowiak, A., Wolko, Ł., Sydow, Z., Kaczorowski, L., Powierska-Czarny, J., Cyplik, P., 2019. The impact of natural and synthetic surfactants on bacterial community during hydrocarbon biodegradation. Int. Biodeter. Biodegr. 142, 191-199.

Tianran, Z., Fuhou, L., Pengfei, L., Chunrui, H., Shijie, L., Jianxin, J., 2019. High Rhamnolipid Production from Cassava Residues by Simultaneous Saccharification and Fermentation with Low Enzyme Loading. J. Biobased Mater. Bioenergy. 13 (5), 635-642.

Tiso, T., Zauter, R., Tulke, H., Leuchtle, B., Li, W.J., Behrens, B., Rosenau, F., Hayen, H., Blank, L.M., 2017. Designer rhamnolipids by reduction of congener diversity: production and characterization. Microb. Cell Fact. 16, 225. https://doi.org/ 10.1186/s12934-017-0838-y.

Tripathi, V., Gaur, V.K., Dhiman, N., Gautam, K., Manickam, N., 2019. Characterization and properties of the biosurfactant produced by PAH-degrading bacteria isolated from contaminated oily sludge environment. Environ. Sci. Pollut. Res. 27, $27268-27278$.
Varjani, S., Joshi, R., Srivastava, V.K., Ngo, H.H., Guo, W., 2019. Treatment of wastewater from petroleum industry: current practices and perspectives. Env. Sci. Pollut. Res. 27, 27172-27180.

Varjani, S., Rakholiya, P., Ng, H.Y., You, S., Teixeira, J.A., 2020a. Microbial Degradation of Dyes: An overview. Bioresour. Technol. 314, 123728 https://doi.org/10.1016/j. biortech.2020.123728.

Varjani, S., Upasani, V.N., 2019. Evaluation of rhamnolipid production by a halotolerant novel strain of Pseudomonas aeruginosa. Bioresour. Technol. 288, 121577 https://doi. org/10.1016/j.biortech.2019.121577.

Varjani, S., Upasani, V.N., Pandey, A., 2020b. Bioremediation of oily sludge polluted soil employing a novel strain of Pseudomonas aeruginosa and phytotoxicity of petroleum hydrocarbons for seed germination. Sci. Total Environ. 737, 139766 https://doi.org/ 10.1016/j.scitotenv.2020.139766.

Varjani, S.J., 2017. Microbial degradation of petroleum hydrocarbons. Bioresour. Technol. 223, 277-286.

Varjani, S.J., Gnansounou, E., Pandey, A., 2017. Comprehensive review on toxicity of persistent organic pollutants from petroleum refinery waste and their degradation by microorganisms. Chemosphere 188, 280-291.

Varjani, S.J., Upasani, V.N., 2016a. Core flood study for enhanced oil recovery through ex-situ bioaugmentation with thermo- and halo-tolerant rhamnolipid produced by Pseudomonas aeruginosa NCIM 5514. Bioresour. Technol. 220, 175-182.

Varjani, S.J., Upasani, V.N., 2016b. Carbon spectrum utilization by an indigenousstrain of Pseudomonas aeruginosa NCIM 5514: production, characterization and surface active properties of biosurfactant. Bioresour. Technol. 221, 510-516.

Varjani, S.J., Upasani, V.N., 2016c. Biodegradation of petroleum hydrocarbons by oleophilic strain of Pseudomonas aeruginosa NCIM 5514. Bioresour. Technol. 222, 195-201.

Varjani, S.J., Upasani, V.N., 2017a. A new look on factors affecting microbial degradation of petroleum hydrocarbon pollutants. Int. Biodeterior. Biodegr. 120, 71-83.

Varjani, S.J., Upasani, V.N., 2017b. Critical review on biosurfactant analysis, purification and characterization using rhamnolipid as a model biosurfactant. Bioresour. Technol. 232, 389-397.

Wang, H., Roelants, S.L.K.W., To, M.H., Patria, R.D., Kaur, G., Lau, N.S., Lau, C.Y., Van Bogaert, I.N.A., Soetaert, W., Lin, C.S.K., 2018. Starmerella bombicola: recent advances on sophorolipids production and prospects of waste stream utilization. J. Chem. Technol. 94 (4), 999-1007.

Wang, H., Tsang, C.W., To, M.H., Kaur, G., Roelants, S.L.K.W., Stevens, C.V., Soetaert, W., Lin, C.S.K., 2020. Techno-economic evaluation of a biorefinery applying food waste for sophorolipid production - a case study for Hong Kong. Bioresour. Technol. 303, 122852 https://doi.org/10.1016/j.biortech.2020.122852.

Wang, Y., Nie, M., Diwu, Z., Lei, Y., Li, H., Bai, X., 2019. Characterization of trehalose lipids produced by a unique environmental isolate bacterium Rhodococcus qingshengii strain FF. J. Appl. Microbial. 127 (5), 1442-1453.

Wei, Y.H., Chou, C.L., Chang, J.S., 2005. Rhamnolipid production by indigenous Pseudomonas aeruginosa J4 originating from petrochemical wastewater. Biochem. Engineer. J. 27 (2), 146-154.

Wei, Z., Wang, J.J., Meng, Y., Li, J., Gaston, L.A., Fultz, L.M., DeLaune, R.D., 2020. Potential use of biochar and rhamnolipid biosurfactant for remediation of crude oilcontaminated coastal wetland soil: Ecotoxicity assessment. Chemosphere 253, 126617. https://doi.org/10.1016/j.chemosphere.2020.126617.

Wu, J., Zhang, J., Zhang, H., Gao, M., Liu, L., Zhan, X., 2019. Recycling of cooking oil fume condensate for the production of rhamnolipids by Pseudomonas aeruginosa WB505. Bioprocess Biosyst. Eng. 42, 777-784.

Ye, J., Huang, W., Wang, D., Chen, F., Yin, J., Li, T., Zhang, H., Chen, G.Q., 2018. Pilot Scale-up of Poly (3-hydroxybutyrate-co -4-hydroxybutyrate) Production by Halomonas bluephagenesis via Cell Growth Adapted Optimization Process. Biotechnol. J. 13 (5), 1800074. https://doi.org/10.1002/biot.201800074.

Yi, G., Son, J., Yoo, J., Park, C., Koo, H., 2019. Rhamnolipid nanoparticles for in vivo drug delivery and photodynamic therapy. Nanomed. Nanotechnol. Biol. Med. 19, 12-21.

Zhao, F., Jiang, H., Sun, H., Liu, C., Han, S., Zhang, Y., 2019. Production of rhamnolipids with different proportions of mono-rhamnolipids using crude glycerol and a comparison of their application potential for oil recovery from oily sludge. RSC Adv. 9 (6), 2885-2891.

Zhao, F., Shi, R., Ma, F., Han, S., Zhang, Y., 2018. Oxygen effects on rhamnolipids production by Pseudomonas aeruginosa. Microb. Cell Fact. 17, 39. https://doi.org/ 10.1186/s12934-018-0888-9. 